
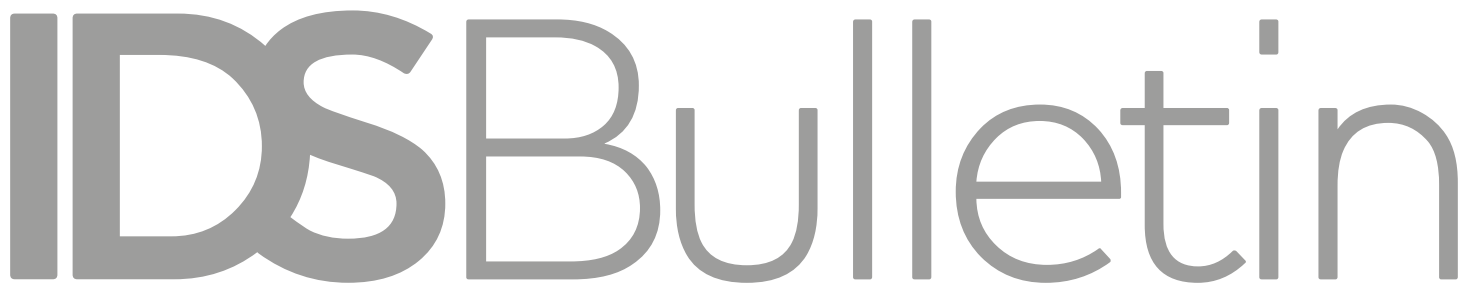

Transforming Development Knowledge

Volume 50 | Number 3 | September 2019

\title{
ACCOUNTABILITY AMIDST FRAGILITY, CONFLICT, AND VIOLENCE: LEARNING FROM RECENT CASES
}

\section{Editor Anuradha Joshi}

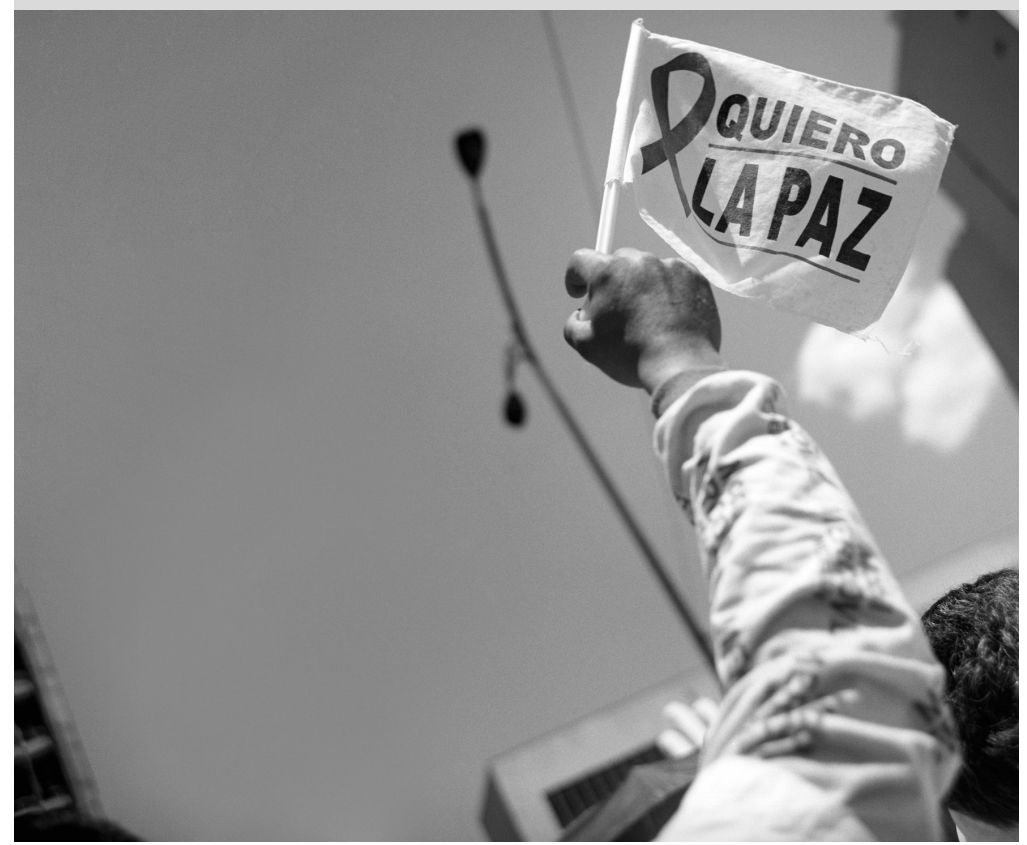


Notes on Contributors

Introduction: Accountability Amidst Fragility, Conflict, and Violence: Learning from Recent Cases

Anuradha Joshi

Myanmar's Top=-Down Transition: Challenges for Civil Society

David Brenner and Sarah Schulman

Youth-Led Anti-Corruption Movement in Post-Conflict Guatemala: 'Weaving the Future'?

Walter Flores

Empowerment without Accountability? The Lawyers' Movement in Pakistan and its Aftershocks

Maryam S. Khan

Localising National Accountability Claims in Fragile Settings: The Right to Food Campaign in India

Anuradha Joshi and Aheli Chowdhury

Civilian Action in Conflict Settings: The Case of Colombia

Patricia Justino

Glossary 


\title{
Introduction: Accountability Amidst Fragility, Conflict, and Violence: Learning from Recent Cases*
}

\author{
Anuradha Joshi ${ }^{1}$
}

\begin{abstract}
Conflict, violence, and fragility exacerbate the difficulties faced by poor and marginalised people, particularly in influencing the policy decisions that affect their lives. Comparing five cases in conflict-affected contexts, this introduction highlights a number of approaches. It emphasises the importance of distinguishing processes of accountability from those of empowerment, and recognising the complexities of the relationships between them. It highlights how the dynamic nature of contexts of fragility, violence, and conflict constrain citizen action but simultaneously offer opportunities for civic actors to form coalitions with new actors and movements. It underscores the value in viewing accountability gains within the longer historical trajectory of particular conflicts. Finally, it illustrates the core importance of narratives and framing in driving collective action and embedding the legitimacy of claims. The cases highlight that progress towards accountability is often transitory and partial, but together also foreground key issues that are relevant for understanding empowerment and accountability processes.
\end{abstract}

Keywords: citizen action, fragility, violence, conflict, post-conflict, accountability, empowerment.

\section{Introduction}

Fragility, conflict, and violence are increasingly common features of countries suffering from high levels of poverty and under-development (OECD 2018). Estimates by the World Bank suggest that by 2030, about half of the world's poor will live in contexts of fragility and conflict. ${ }^{2}$ Such contexts are often ones where state institutions are weak, fragmented, and lack legitimacy; ${ }^{3}$ where non-state actors control territory and often provide services, and where civic space is limited and uneven. The big question is: under these circumstances, whether, how, and under what conditions can citizen-led action lead to more accountable and responsive institutions (state or non-state)? 
Historically, in countries with stable/consolidated states, accountability and responsiveness to marginalised groups have often emerged through grass-roots struggles - bear in mind the civil rights movement in the US and the apartheid movement in South Africa. Those struggles are wellstudied signposts in the history of progress and have been markers of how we think about transformational change. Drawing from those historical experiences and others, a substantial body of literature on accountability emerged that highlighted the centrality of information to accountability claims (Fox 2007; Fung, Graham and Weil 2007), the importance of facilitation or mediation of citizen claims (Barr et al. 2012; von Lieres and Piper 2014; Shankland 2014), vertical integration, coalition building (Fox 2016), multi-pronged approaches (Joshi 2017), and the need to think of accountability as a long-term political process that shifts relationships between citizens and states (Joshi and Houtzager 2012). Yet, these insights have been borne out of the experiences of relatively stable states.

Much has changed in the last 20 years. Two decades ago, there was an air of optimism around the possibilities of gaining accountability through empowerment from below. There was an assumption that it was just a matter of time before countries affected by authoritarianism, conflict, and fragility would move towards democracy and related accountabilities. At present, we observe the opposite: increasingly, relatively robust democracies are becoming less so - nationalism, populism, and religious fundamentalism are on the rise. There has been a seismic shift in the ways in which both citizens and state institutions can connect and mobilise through the internet and related social media (McGee et al. 2018; McGee and Edwards 2016).

Consequently, sources of information are multiple and often contradictory, making it difficult to base behaviour on facts. Growing inequality in most regions of the world widens class divides and undermines visions of a common future. Fragility, conflict, and violence seem to be spreading rather than receding. And there has been a growing distrust in state institutions throughout the world, a feature that is heightened in settings of fragility, violence, and conflict. This makes the challenge of understanding and conceptualising the potential for social and political action and its effects on empowerment and accountability in these kinds of contexts even more urgent and daunting. How far do our insights from stable settings hold?

The Action for Empowerment and Accountability (A4EA) research programme under which this research was undertaken makes a small start towards this enormous task of understanding how progress can be made on empowerment and accountability in fragile, conflict-, and violence-affected settings (FGVAS). ${ }^{4}$ What this IDS Bulletin hopes to do is to look back at recent history and identify insights from relatively recent experiences of grass-roots struggles and related social and political change that contributed to transitory progress towards greater accountability of public institutions in these contexts. We say 'transitory progress' because examples of unqualified successes are rare, and it 
seems too early to tell whether the progress viewed today is likely to continue. In many of the cases presented here, the changes observed have been partial, uneven, and fragile - with setbacks already observed in some cases, and real possibilities of reversals in others. Yet, even these accounts of partial progress can tell us something about the pathways through which accountability might be sought and strengthened, and the conditions that enable fruitful navigation of the uncertain and changing terrain in fragile, conflict-, and violence-affected contexts.

The five cases presented here - transition to democracy in Myanmar, civilian action in pre- and post-conflict Colombia, the anti-corruption protests in Guatemala, the lawyers' movement for judicial autonomy in Pakistan, and the spread of the 'Right to Food' campaign to subnational levels in India - were chosen as they are cases where we can see some progress on pathways towards accountability, however nascent or temporary. We prioritised accountability in the case selection because these cases are rare, and require a shift in citizen-state relations. Each case explores the dynamics of empowerment and accountability, and their interactions.

The cases represent a variety of histories of conflict and potential pathways to accountability through political and institutional change: from the oldest running civil conflict in the world in Myanmar, to the relatively recent post-conflict peace in Colombia, to the geographically localised conflicts witnessed in India's Naxal-affected states. They range from long-standing authoritarian regimes such as Myanmar, to countries where military rule has alternated with periods of democracy as is the case in Pakistan, to formal democracies such as India. The reasons for the ongoing conflicts also vary in substance - including among the immediate causes: the rise of religious fundamentalism in Pakistan, repressive regimes targeting ethnic groups such as the case of Guatemala, and more extreme left-oriented movements such as the Naxalites in India.

Collectively, the articles in this IDS Bulletin highlight four key issues that are central in understanding how accountability pathways unfold in contexts of fragility, violence, and conflict. First, processes of accountability have to be distinguished from processes of empowerment and strengthening agency. Empowerment gains might be achieved without gaining accountability, and, (though less likely) institutional responsiveness might not lead to any empowerment. Understanding the conditions that will foster empowerment and accountability processes independently is important in order to get better analytical purchase on the outcomes we observe. And the outcomes themselves are more likely to be precursors, such as overcoming fear and building trust, to the more conventional empowerment and accountability outcomes that are expected.

Second, the cases show how the particular dynamic nature of these contexts - fragility, violence, and conflict - is constraining; but can simultaneously offer opportunities for civic actors to form coalitions with new actors and movements that enable some traction in the struggle for 
public accountability. At critical junctures, the institutional constraints on agency are momentarily relaxed and provide openings for new configurations of power to be sought and in some cases established (Acemoglu and Robinson 2012; Capoccia 2015; Capoccia and Kelemen 2007; Houtzager 2003).

However, such coalitions by their nature are tricky and constantly in flux; and point to the staggered, non-linear nature of progress - where gains can be made as well as lost within a short period of time. Indeed, the cases suggest that any progress in the pathways to accountability inevitably invite backlash: in at least three of the countries - Guatemala, Myanmar, and Colombia - there has been serious backsliding regarding accountability since the cases were selected and written up. In the other two countries - India and Pakistan - there has been a serious shrinkage of civic space for activism of the kind described here.

Third, the cases underscore that although such contexts are characterised by rapidly changing political and policy configurations, episodes of claim-making and resistance have to be viewed within the longer historical trajectory of conflict in order to understand why and how they occur, and the impacts they might have. This includes prior experiences with collective mobilisation, the generational internalisation of fear and trauma, and the constraints those place on people's agency. Simultaneously, those experiences require an examination of the governance structures - the basis on which those holding power have exercised authority over time without constantly resorting to force. The 'stickiness' of institutional and people's responses in the conflict period circumscribe the actions of both public authorities and people in the present. Specifying precisely how one affects the other is a task taken up by several articles.

Fourth and finally, following the broader social movements literature, these analyses of political and institutional change in FGVAS foreground the role of narratives in driving collective action and embedding the legitimacy of claims. Particularly in FCVAS, where the formal and rational might have less traction than in stable political environments, ideas and emotions seem to be particularly important in mobilising people. Obviously, this is not a new strategy, especially for political entrepreneurs, parties, and social movements. Yet, these cases show ways in which new framings can help create new allies, build coalitions, and mobilise the general public.

Before elaborating on these issues, we need to clarify conceptually how accountability processes in FCVAS might be different from more stable settings. Section 2 takes up this task.

\section{Rethinking accountability processes in FCVAS}

In the past few years, there has been a lot of attention paid to understanding how citizen-led social and political action might lead to accountability. Often under the rubric of 'social accountability', we have 
new insights into the value of vertical integration of pro-accountability efforts, the importance of scaling up local successes through various pathways, and the need for alliances with strategic pro-reform actors both within and outside the state at different levels (Aceron 2018; Fox 2007, 2015, 2016; Pande 2008; Pande and Houtzager 2016). Yet, most of these insights emerge from relatively well-functioning settings - with cohesive and effective states, well-established civic and political institutions, open societies, relatively free media, vibrant civil societies, and at least some adherence to formal rules and processes. How well do these insights matter in FCVAS?

Our starting point in this IDS Bulletin is that because contexts affected by fragility, violence, and conflict differ significantly from more stable ones, we are likely to observe different processes at work here, particularly in relation to empowerment and accountability, as even the terms 'empowerment' and 'accountability' need to be understood contextually. Why? Three reasons stand out.

First, the features of context. In the places we are examining, significant parts of the country, often in the borderlands, are affected by fragility, conflict, and violence. These are places where state capacity to deliver public services is low, state institutions are weakly embedded, and parts of the country have little or no state presence; what O'Donnell (1994) terms 'brown areas' or others have termed areas of 'limited statehood' (Risse and Stollenwerk 2018; Risse, Börzel and Draude 2018). The pockets of fragility, violence, and conflict do not mean that the state itself is weak (where it is weak, however, it is by definition a brown area); often, it is authoritarian, with a strong capacity for repression.

Such states rely on external or point sources of revenue (e.g. aid or extractives). Democracy remains nominal at the level of regular elections, sometimes only a little less than free and fair, but there is little in the form of a deeper democratic culture. In the pockets of FGVAS, alternative sources of authority often coexist or dominate in the form of armed/non-armed groups based on ethnicity/religious or private interests that often overlap. Informal actors, institutions, and processes prevail, and power flows through non-formal, invisible channels that circumscribe action. Ethnic, religious, and other intersecting identities trump over secular, citizenship-based ones.

And social norms and perceptions of particular actors shape attitudes and behaviour in terms of action for accountability. Simultaneously, the internalisation of fear and trauma borne out of long periods of conflict and violence lead people to self-censor - and inaction manifests as a rational strategy for the poor and most marginalised: what Pettit (2016) calls 'civic habitus'. In such areas, 'ruling' or 'governance', that is, the process through which social coordination occurs in order to produce and implement collectively binding rules or public goods, depends upon the legitimacy of state (or non-state) actors, as it enables rule without constantly resorting to force. 
For nascent democracies such as Myanmar or South Sudan, with limited capacities and untested political settlements, such legitimacy has been posited as critical for stability and preventing deterioration into further conflict; for example, see the recent report of the Commission on State Fragility, Growth and Development (2018). Yet, as many authors have noted, there are diverse sources of legitimacy, beyond the traditional sources of input, process, output, and legal legitimacy - including social trust, traditional or religious, ethnic identity-based, or even charismatic leadership-based legitimacy. In areas of limited statehood, Risse and Stollenwerk (2018) suggest that 'empirical legitimacy' - the social acceptance by the population of the state's right to rule - is critical for understanding governance effectiveness, as the presence of such empirical legitimacy leads to voluntary compliance. In 'brown areas' or areas of 'limited statehood', the big question then is how to understand the conditions and processes through which low-trust, low-legitimacy environments can be moved to be more accountable and evolve into higher trust, more empirically legitimate, accountability-oriented environments.

Second, given the challenges of the contextual conditions described above, social and political action for accountability cannot be expected to occur in predictable forms. The limited space for civil society means that action is likely to take grass-roots, customary, spontaneous, and cultural forms. Disruption, non-traditional forms of protest and, at least on the face of it, seeming lack of organisation are features that we are likely to observe. The locations of such collective action are also likely to be non-traditional - virtually rather than in face-to-face organisations, anonymously rather than through known opposition groups, or through old repertoires appropriated by unexpected actors.

Such action is more likely to be nebulous and fluid, or even 'eruptive', and connections between action in different spaces less obvious. Violence itself might be a form of social and political action, viewed as a last resort for people who are desperate. The targets of action are also diverse - from state institutions to non-state actors, including religious bodies, armed groups, or private sector actors - and might involve seeking to mobilise some of them to influence others.

Finally, the big challenge is defining what is empirically meant by accountability, or even a reasonable expectation of what accountability might look like in such settings - how will we know it when we see it? Accountability might not even have the same meaning given the differences in culture, experience, and expectations. Expecting that public officials will routinely provide justifications for their actions to the populace and accept any judgements and sanctions/rewards rendered (the traditional definition of accountability) in these settings is improbable. So realistically, we are unlikely to observe the clear and big accountability gains that social and political action has led to in stable settings, such as the right to information in India or the institutionalisation of participatory governance councils in Brazil. 
In fact, we are unlikely to even get the kinds of smaller gains made by localised social accountability initiatives that have been tried in many countries. Rather, we are more likely to encounter the need for fostering enabling environments - that is, some public transparency, space for civic action, and so forth - that are precursors to empowerment and accountability. And progress on overcoming fear and trauma; incremental trust building; developing citizens' awareness and expectations of state institutions; catalysing instances of responsiveness; and bolstering social actors' cohesion, so that if and when the broader context opens up, they will be better positioned to emerge and grow both vertically and horizontally; these are the kinds of outcomes that we can expect and commend.

\section{Cases of transitory progress?}

The cases presented here represent transitory progress on accountability and unpack the interacting roles different sets of social and political actors have played in their relative success. We briefly review the cases, before drawing out some thematic lessons in Section 4.

One set of cases focuses directly on social actors to understand the conditions that enable them to achieve their objectives. Flores (this IDS Bulletin) traces the case of recent anti-corruption protests in Guatemala by examining the strategies employed by the activists. In March 2015, Guatemalan youth, tired of the corruption exposed through a report of the CICIG (the International Commission Against Impunity in Guatemala - a UN-backed autonomous body created to look into breaches of integrity in government) called for a peaceful non-partisan protest in the capital under the banner, 'Renuncia $\mathrm{Ya}^{\prime}$ ', demanding the immediate resignation of the president. The response to the call was overwhelming and protests continued every Saturday in cities across Guatemala until the president was forced to resign. Given the long-standing problem of corruption embedded in public services in Guatemala, this was, ten years later, a significant, albeit limited, victory for the anti-corruption movement. Yet because of elite backlash, CICIG is now being closed down.

Joshi and Chowdhury (this IDS Bulletin) trace how relatively successful national rights campaigns can reach back to the grass roots and mobilise in conflict-affected locations. Examining the evolution of the Right to Food (RTF) campaign in the Naxalite-affected states in India, they show how social movements fighting for the government to respect socioeconomic rights can emerge and thrive in areas where they might compete with armed groups (termed left-wing extremists (LWEs) by the state), for credibility and support of local populations. Their ability to do so depends, they argue, on the overlap in geographic areas and issues between the RTF campaign and armed groups. In the case of rights campaigns in India, LWEs did not obstruct the work of the RTF campaign, as LWEs were not able to deliver on the basic needs of the people, due to their limited resources. In fact, the tension between the RTF campaign's goal of making the state 'work' for the people, and the 
LWEs' struggles that rejected the legitimacy of the state, enabled the RTF campaign to establish roots in these locations.

Similarly, Khan (this IDS Bulletin) follows the Lawyers' Movement in Pakistan and its efforts towards re-establishing judicial independence and empowering the judiciary, from the brief period between the dismissal of the Chief Justice in 2007 and the resignation of President Musharraf in 2009. Identifying five distinct phases of the movement, she shows how the alliances forged between lawyers and the judiciary, with the support of opposition political parties led to re-establishing judicial autonomy. And yet, as she shows, the conditions and strategies that led to success also ironically later led to the judiciary gaining too much power, enabling it to resist calls for its own accountability. Further, the alliances forged between sections of the bar, the bench, and opposition parties in the earlier period of seeking judicial independence, were reconfigured in the latter civilian period, and new lines of cleavage opened within the bar and the bench along party political lines.

The remaining articles take a broader look at cases of accountability where there have been transitions to new institutional settings - the transition to democracy in Myanmar (Brenner and Schulman, this IDS Bulletin) and the progress towards peace in Colombia (Justino, this IDS Bulletin). In both, the role of social actors and their contributions to the shifts are not direct or given; they have to be 'read' through unearthing their contribution over time, from the period of conflict to the post-conflict situation. Both articles argue that how social and political actors make demands in the period immediately following conflict is shaped by their experiences during the conflict.

Brenner and Schulman (this IDS Bulletin) argue that the long historical roots of the political transition in Myanmar shape the possibilities and contours of social and political action in the present. The role of the British during colonial rule was to exacerbate fragmentation and social cleavages through preferential treatment of ethnic minorities in the army, enlisted to control the Bamar population. They show how the political transition was orchestrated by the Burmese military skilfully consolidating its political and economic power. The role of social and political action in such a context has been limited, fragmented, sporadic, and has been consistently opposed by the regime. These tensions continue to linger, and greater fragmentation post-transition has led not only to a proliferation of civil actors, but also to a thriving 'uncivil' society which actively fosters social divides and cements narrow notions of identity.

Drawing upon the case of Colombia, Justino (this IDS Bulletin) describes how both guerrilla and paramilitary groups took control over territory at different points of time during the conflict over the past several decades. She develops a conceptual typology of social and political action by population, based on whether armed groups are predatory or seek to dominate by establishing rules. She further breaks down social 
and political action in each of these contexts based on the institutional and economic capacity of social actors, as well as whether their interests are aligned with those of the armed group or not. Using this typology and evidence of population response to rule in Colombia, she argues that those social groups that were able to resist armed groups during the conflict have been better able to push open space for their participation in the peace process. Yet those same activists committed to building peace in presumably former conflict zones are now at risk from a resurgence of diverse armed actors.

Together these cases offer insights into a range of issues that are central to the empowerment and accountability agenda in contexts of fragility, conflict, and violence. We turn to these in the next four sections.

\section{Disentangling empowerment and accountability}

Those working on empowerment and accountability tend to assume that they are automatically mutually supportive of one another or that they exist in a virtuous cycle. Our cases show that, particularly in FCVAS, these more often than not follow distinct paths. We trace some of the issues that are raised by the cases next.

A critical point is who is being empowered (and who might be getting disempowered). In FCVAS, as elsewhere, social actors are not homogenous and processes of social and political action that empower one group, often do so at the cost of others. Brenner and Schulman (this IDS Bulletin) suggest that in Myanmar, donors who were funding civil society groups active in border regions during the pre-transition period, started channelling funds in the post-transition period to support government programmes, leading to a crisis for organisations who were dependent upon aid for their activities. As they show, this has led to a debate between donors advocating for continued cross-border aid (support to civil society organisations (CSOs) in the borderlands) to avoid disruption of services, and donors propagating aid through Yangon and government channels.

Simultaneously, the experience of resisting during the conflict can empower communities to be more active during the post-conflict period. In Colombia, Justino (this IDS Bulletin) drawing on Moser (2005) and others notes how women who have actively participated in the peace process report raised levels of self-esteem, which leads to a virtuous cycle of greater participation. By contrast, the experiences of extreme violence and repression during the conflict in Guatemala led to an atmosphere of fear and disempowerment in the post-conflict period, and it took a new generation of youth to take to the streets to break the cycle of inaction and demand accountability from the government.

Moreover, the empowered actors in our cases are not always in favour of accountability. As Khan (this IDS Bulletin) shows in the case of the Lawyers' Movement in Pakistan, the movement was keen to empower the judiciary and ensure its independence as a key institution for 
political accountability, and yet the judiciary, once empowered resisted calls for its own accountability. As she summarises pithily, the conditions that make lawyers pro-empowerment actors may not make them pro-accountability agents.

And accountability itself in these cases is difficult to assess. There are the rare instances of responses on the part of the government, but though the claims and responses are linked, they represent instances of accountability rather than ongoing accountability relationships between citizens and the state. In these instances, authorities routinely provide information and justification for their actions, opening themselves up to the judgement of the public through a process of deliberation. In Guatemala and Pakistan, the positive response was followed by a reversal in terms of powerful actors preventing pro-accountability coalitions from gaining ground.

\section{Unexpected coalitions and cleavages}

The cases of transitional success in establishing precursors for accountability and empowerment highlighted here also show the possibilities for unexpected coalitions for change, as well as the development of new cleavages. In several cases, if analysed through a historical institutionalist lens, there were critical junctures - defined as a 'relatively short period of time during which there is a substantially heightened probability that agents' choices will affect the outcome of interest', that opened up the space for pro-accountability forces to collaborate through new configurations that challenged the existing status quo (Capoccia and Kelemen 2007: 348).

In Guatemala, a reformist public prosecutor backed by the CICIG was able to provide credible information on large-scale political corruption that contributed to the rise of the youth protests. This resulted in what Jonathan Fox has called a 'sandwich strategy', which forced a corrupt government out of office by applying pressure through the reformist public prosecutor and the CICIG from above, and through protests in the street from below (Fox 2015). And yet, this did not lead to consolidation of the anti-corruption coalition. After the resignation of the president, the youth movement splintered into two groups: those who supported a neoliberal agenda and those who aligned with the traditional left, indigenous, and peasant movements. Neither did the alliance between the public prosecutor and CICIG last long - the next president 'directed much of his government's energies over the past two years to trying to strip CICIG of its authority' (Malkin 2019).

Similarly, the Lawyers' Movement in Pakistan started from an unexpected alliance between lawyers and judges reacting to the growing public anti-regime sentiment and an attack on the judiciary by a person in uniform, borne out of institutional motivations of preserving the institutional autonomy of both the bar and the bench against an extraconstitutional regime (Khan, this IDS Bulletin). And yet once the battle was won and autonomy was institutionalised, alliances 
re-fractured in new ways, creating a situation where only some parts of the bar and bench were fighting for accountability. In India, a strategy of constructive engagement with the state on basic food security and simultaneous advocacy supported by the national campaign, enabled the Right to Food campaign to distinguish itself from LWE groups at the state level, by not taking up the issues of displacement and land rights which were core to the LWEs' agenda. Yet, since the passing of the Right to Food Act in 2014, there has been greater acknowledgement of the need to work on issues of displacement and land rights by the national RTF campaign; at the same time there are new cleavages emerging among LWEs, thus blurring the stark LWE/RTF positions from the earlier period.

\section{History shapes possibilities}

It is an oft-repeated refrain that history affects the present; yet we need to unpack precisely how it does so. Most obviously, in FGVAS, it is history that produced the conflict, fragility, and fragmentation that actors have to deal with in the present period. What are the factors that linger and cast constraints on actors? Scholarship in the historic institutionalist tradition has stressed the staying power of institutions, through the notion of path dependence - decisions taken at 'critical junctures' then reconfigure institutions and set in motion a new set of constraints within which change once again only happens incrementally.

But in FCVAS settings (and perhaps in others) when viewed from an accountability and empowerment lens, a double whammy effect might result. In what we might call 'institutional overhang', structures developed for repression and control become a drag on the new democratic processes. Constraints such as fear and reticence that made sense and were strategies adapted for a previous political period of conflict, become millstones for accountability action in the post-conflict setting. Further, often the momentary opening of space and responses to claims - what we might see as accountability gains - turn out to foster a new set of constraints that make future accountability struggles even more challenging.

As we see in the cases of Colombia, Guatemala, and Myanmar, identities and fear forged and reinforced during the trauma continue to shape behaviours of the present. In Guatemala, it took a new generation of urban youth to mobilise on social media and challenge state structures; far away geographically and temporally from the violence experienced in rural areas by the older generation. Brenner and Schulman (this IDS Bulletin) take the long view of the history of Myanmar to highlight how British colonial rule set ethnic minorities at the border against the heartland Bamar groups. This not only created conditions for the conflict post-independence, but also cast a shadow over the political transition, limiting possibilities for cooperation as advantages and disadvantages have become institutionally embedded for different groups. In India, the long history of the LWE groups and their position vis-à-vis working with the state created an opportunity 
for RTF activists to work on food security despite working in the same terrain, and yet the same history limits the possibilities of what the RTF activists can do in the area in terms of direct confrontation or challenges to the state which would be seen akin to 'terrorist' activity similar to that of the extremist groups.

\section{Framing the narratives}

While ideas and narratives about values and imagination have been seen as an important tool for mobilising action, particularly in the social movement literature (Benford and Snow 2000; Snow and Benford 1988; Gamson 1992), they have received less attention in the donor and project-focused accountability work which has tended to be initially more technical, and only recently more political. Unpacking cases of success as being underpinned by the mobilising power of narratives, of framing claims as stories of moral rights and wrongs, bestowing legitimacy on the claimants through socially accepted moral norms - what might be called the contemporary moral economy - is relatively recent (Hossain and Scott-Villiers 2017; Hossain and Kalita 2014; Thompson 1971). And yet, as these cases show, lurking behind the processes driven by institutions and interests are stories of where particular frames appear to be galvanised by social actors to advance their cause. A few illustrations follow.

In Pakistan, what was initially considered by the populace as a single narrow issue, was given different guises at different moments to different audiences. As Khan (this IDS Bulletin) writes, the bar leaders played a pivotal role in constructing these multiple yet cohesive narratives to respond to a rapidly evolving political situation. These efforts were supported by a significant moment in the mobilisation when the hearings on the case were allowed on camera, as they further served to mobilise public opinion, which until then had largely regarded these hearings as an issue limited to the courts. Similarly, as we will see, the Indian RTF campaign in the Naxal-affected states used the 'right to food' framing to gather together a range of development issues that different groups were already working on (from subsistence agriculture to children's rights) under a collective umbrella.

This broad church strategy not only gained it a diverse membership, but the rights framing also directed efforts at the accountability of the state (the duty bearer), allowing the campaign to underscore that it was interested in working with the state to make the state work for the poor, rather than posing a threat to its very existence. In Guatemala, the students mobilised under the banner of 'anti-corruption', which they portrayed as apolitical, a matter of good governance; thus constructing a popular common cause that appealed across class, ethnic, and political affiliations. However, as Flores (this IDS Bulletin) outlines, the movement later quickly broke up into different ideological streams, diluting the movement as well as its broader appeal. 


\section{Conclusions}

This IDS Bulletin set out to look at recent history for lessons on how progress on empowerment and accountability might be made in contexts of fragility, conflict, and violence. The five cases presented here offer rough contours of the issues and their conceptual underpinnings that might be relevant for understanding and conceptualising empowerment and accountability processes in such settings. Taken collectively, the set of cases show that progress is possible in the conflict/post-conflict context despite the unfavourable terrain, but the paths that social action takes is heavily constrained by local understandings of empowerment and accountability, the configuration of pro-accountability stakeholders, the history of the conflict and its effects on various groups, and how narratives are mobilised to serve political change. Moreover, any progress, we note, is transitory: it can and has been reversed. Whether or not social action is durable and has accountability effects, can only be judged over the long term.

As pockets of fragility, conflict, and violence emerge in what have so far been relatively stable places, initial insights from these cases will be increasingly relevant for tackling these issues globally. Foremost, it seems clear that processes of accountability and empowerment each move at a different pace, following their own trajectories and are only loosely linked. And yet, in each of the cases, there are moments of opportunity when things shift and new political configurations enable new coalitions and action to become possible, which may or may not lead to accountability and empowerment gains.

One of the key findings seems to be that processes of empowerment and accountability are more likely to unfold when some precursors are in place that would lay out the foundations of the pathways. A legacy of conflict and repression, it turns out, plays a big part in shaping how actors respond to the opportunities. And the cases show that the battle for accountability is not only fought through formal institutions and against deeply entrenched interests, but also in the battlefield of ideas, where simple strategies of framing or reframing can shift the advantage in favour of accountability in the eyes of the public at large.

\section{Notes}

* This issue of the IDS Bulletin was prepared as part of Action for Empowerment and Accountability (A4EA), an international research programme exploring social and political action in fragile, conflict, and violent settings. A4EA is a consortium led by IDS and funded with UK aid from the UK government. The views expressed do not necessarily reflect the official policies of our funder.

+ I am grateful for the incredibly helpful comments provided by Colin Anderson, Jonathan Fox, John Gaventa, and Peter Houtzager on an earlier version of this article.

1 Anuradha Joshi, Research Fellow, Institute of Development Studies, UK. 
2 See World Bank: www.worldbank.org/en/topic/ fragilityconflictviolence/overview.

3 State weakness in the sense of the capacity and willingness to organise the provision of public goods; often, they are strong in terms of repression and military power.

4 For details of the A4EA programme, see www.ids.ac.uk/programmeand-centre/action-for-empowerment-and-accountability-a4ea/.

\section{References}

Acemoglu, D. and Robinson, J.A. (2012) Why Nations Fail: The Origins of Power, Prosperity and Poverty, New York NY: Crown Publishers

Aceron, J. (ed.) (2018) Going Vertical: Citizen-Led Reform Campaigns in the Philippines, 2nd ed., Quezon City: G-Watch, www.g-watch.org/ resources/vertical-integration-research/going-vertical-citizen-ledreform-campaigns-philippines-2nd (accessed 10 June 2018)

Barr, A.; Mugisha, F.; Serneels, P. and Zeitlin, A. (2012)

'Information and Collective Action in Community-Based Monitoring of Schools: Field and Lab Experimental Evidence from Uganda', draft paper, https://pdfs.semanticscholar. org/99f5/806ab361f3308d652b9549b390e4f183b672.pdf (accessed 12 August 2019)

Benford, R.D. and Snow, D.A. (2000) 'Framing Processes and Social Movements: An Overview and Assessment', Annual Review of Sociology 26.1: $611-39$

Capoccia, G. (2015) 'Critical Junctures and Institutional Change', in J. Mahoney and K. Thelen (eds), Advances in Comparative-Historical Analysis, Cambridge: Cambridge University Press

Capoccia, G. and Kelemen, R.D. (2007) 'The Study of Critical Junctures: Theory, Narrative, and Counterfactuals in Historical Institutionalism', World Politics 59.3: 341-69

Commission on State Fragility, Growth and Development (2018) Escaping the Fragility Trap, London: Commission on State Fragility, Growth and Development, www.theigc.org/wp-content/ uploads/2018/04/Escaping-the-fragility-trap.pdf (accessed 12 August 2019)

Fox, J. (2016) Scaling Accountability through Vertically Integrated Civil Society Policy Monitoring and Advocacy, Making All Voices Count Working Paper, Brighton: IDS, www.ids.ac.uk/publications/scalingaccountability-through-vertically-integrated-civil-society-policymonitoring-and-advocacy/ (accessed 12 August 2019)

Fox, J. (2015) 'Social Accountability: What Does the Evidence Really Say?', World Development 72: 346-61

Fox, J. (2007) Accountability Politics: Power and Voice in Rural Mexico, Oxford: Oxford University Press

Fung, A.; Graham, M. and Weil, D. (2007) Full Disclosure: The Perils and Promise of Transparency, New York NY: Cambridge University Press

Gamson, W.A. (1992) Talking Politics, Cambridge: Cambridge University Press 
Hossain, N. and Kalita, D. (2014) 'Moral Economy in a Global Era: The Politics of Provisions during Contemporary Food Price Spikes', Fournal of Peasant Studies 41.5: 815-31

Hossain, N. and Scott-Villiers, P. (2017) Food Riots, Food Rights and the Politics of Provisions, Abingdon: Routledge

Houtzager, P. (2003) 'Introduction: From Polycentrism to the Polity', in P. Houtzager and M. Moore (eds), Changing Paths: International Development and the New Politics of Inclusion, Ann Arbor MI: University of Michigan Press

Joshi, A. (2017) 'Legal Empowerment and Social Accountability: Complementary Strategies Toward Rights-Based Development in Health?', World Development 99: 160-72

Joshi, A. and Houtzager, P. (2012) 'Widgets or Watchdogs? Conceptual Explorations in Social Accountability', Public Management Review 14.2: 145-62

Malkin, E. (2019) 'Guatemala's Presidential Election may be a Blow to Anti-Corruption Effort', New York Times, 17 June, www.nytimes.com/2019/06/17/world/americas/guatemalaelection.html? searchResultPosition=1 (accessed 12 August 2019)

McGee, R. and Edwards, D. (2016) 'Introduction: Opening Governance - Change, Continuity and Conceptual Ambiguity', IDS Bulletin 47.1: 3-23, https://bulletin.ids.ac.uk/idsbo/article/view/32 (accessed 12 August 2019)

McGee, R.; Edwards, D.; Hudson, H.; Anderson, C. and Feruglio, F. (2018) Appropriating Technology for Accountability: Messages from Making All Voices Count, Making All Voices Count Research Report, Brighton: IDS, www.ids.ac.uk/publications/appropriating-technology-foraccountability-messages-from-making-all-voices-count/ (accessed 30 June 2019)

Moser, C. (2005) 'Peace, Conflict, and Empowerment: The Colombian Case', in D. Narayan (ed.), Measuring Empowerment: Cross-Disciplinary Perspectives, Washington DC: World Bank

O’Donnell, G. (1994) 'Delegative Democracy', fournal of Democracy 5.1: $55-69$

OECD (2018) States of Fragility 2018, Paris: OECD Publishing, https://dx.doi.org/10.1787/9789264302075-en (accessed 30 June 2019)

Pande, S. (2008) 'The Right to Information and Societal Accountability: The Case of the Delhi PDS Campaign', IDS Bulletin 38.6: 47-55, https://bulletin.ids.ac.uk/idsbo/article/view/805 (accessed 12 August 2019)

Pande, S. and Houtzager, P. (2016) Civil Society Innovation and Resilience in the Struggle for the Right to Food in India, IDS Working Paper 475, Brighton: IDS, www.ids.ac.uk/publications/civil-society-innovationand-resilience-in-the-struggle-for-the-right-to-food-in-india/ (accessed 12 August 2019)

Pettit, J. (2016) 'Why Citizens don't Engage - Power, Poverty and Civic Habitus', IDS Bulletin 47.5: 89-102, https://bulletin.ids.ac.uk/idsbo/ article/view/2794 (accessed 12 August 2019) 
Risse, T. and Stollenwerk, E. (2018) 'Legitimacy in Areas of Limited Statehood', Annual Review of Political Science 21.1: 403-18

Risse, T.; Börzel, T.A. and Draude, A. (eds) (2018) The Oxford Handbook of Governance and Limited Statehood, Oxford: Oxford University Press

Shankland, A. (2014) 'Mediation as Diplomacy: Dynamics of Governance and Representation in Brazilian Indigenous Societies', in B. von Lieres and L. Piper (2014) (eds), Mediated Citizenship: The Informal Politics of Speaking for Citizens in the Global South, Basingstoke: Palgrave Macmillan

Snow, D.A. and Benford, R.D. (1988) 'Ideology, Frame Resonance, and Participant Mobilization', International Social Movement Research 1: 197-217

Thompson, E.P. (1971) 'The Moral Economy of the English Crowd in the Eighteenth Century', Past and Present 50.1: 76-136

von Lieres, B. and Piper, L. (2014) Mediated Citizenship: The Informal Politics of Speaking for Citizens in the Global South, Basingstoke: Palgrave Macmillan 